\title{
Warm ocean is eroding West Antarctic Ice Sheet
}

\author{
Andrew Shepherd, ${ }^{1}$ Duncan Wingham, ${ }^{2}$ and Eric Rignot ${ }^{3}$ \\ Received 26 July 2004; revised 7 September 2004; accepted 7 October 2004; published 9 December 2004.
}

[1] Satellite radar measurements show that ice shelves in Pine Island Bay have thinned by up to $5.5 \mathrm{~m} \mathrm{yr}^{-1}$ over the past decade. The pattern of shelf thinning mirrors that of their grounded tributaries - the Pine Island, Thwaites and Smith glaciers - and ocean currents on average $0.5^{\circ} \mathrm{C}$ warmer than freezing appear to be the source. The synchronised imbalance of the inland glaciers is the result of reduced lateral and basal tractions at their termini, and the drawdown of grounded ice shows that Antarctica is more sensitive to changing climates than was previously considered. INDEX TERMS: 1640 Global Change: Remote sensing; 1827 Hydrology: Glaciology (1863); 1863 Hydrology: Snow and ice (1827); 4207 Oceanography: General: Arctic and Antarctic oceanography; 9310 Information Related to Geographic Region: Antarctica. Citation: Shepherd, A., D. Wingham, and E. Rignot (2004), Warm ocean is eroding West Antarctic Ice Sheet, Geophys. Res. Lett., 31, L23402, doi:10.1029/2004GL021106.

[2] During the past decade, the grounded Amundsen Sea (AS; Figure 1) sector of the West Antarctic Ice Sheet (WAIS) has lost $51 \pm 9 \mathrm{~km}^{3}$ of its volume each year due to an imbalance between snow accumulation and ice discharge [Wingham et al., 1998; Shepherd et al., 2002]. While some of the reduction may reflect short-term snowfall variability, a flow disturbance is responsible for removing at least $17 \pm 2 \mathrm{~km}^{3} \mathrm{yr}^{-1}$ of ice from the fast-flowing trunks of the Pine Island (PIG), Thwaites (TG) and Smith (SG) glacier drainage systems [Shepherd et al., 2001, 2002]. Satellite observations of grounding line retreat [Rignot, 1998] and increased ice discharge [Rignot et al., 2002] have shown other aspects of this same disturbance. If the AS sector elevation change is due entirely to dynamic ice thinning, the sector has been a source of ocean mass equivalent to a $0.13 \pm 0.02 \mathrm{~mm} \mathrm{yr}^{-1}$ rise in eustatic sea level for at least 9 years. Since a retreat may lead to accelerated ice discharge from the WAIS interior [Mercer, 1978] sufficient to raise global sea levels by over $1 \mathrm{~m}$, an understanding of the origin and evolution of the present-day mass imbalance is of considerable interest.

[3] Speculation as to the source of the AS sector imbalance has considered the effects of both internal and external disturbances [Schmeltz et al., 2002; Thomas and Rignot, 2004; Joughin et al., 2003; Payne et al., 2004]. Results of computer simulations are equivocal; the pattern of ice thinning and acceleration at the PIG is reproduced through

\footnotetext{
${ }^{1}$ Centre for Polar Observation and Modelling, Scott Polar Research Institute, University of Cambridge, Cambridge, UK.

${ }^{2}$ Centre for Polar Observation and Modelling, University College London, London, UK.

${ }^{3}$ Jet Propulsion Laboratory, California Institute of Technology, Pasadena, California, USA.
}

Copyright 2004 by the American Geophysical Union. 0094-8276/04/2004GL021106 modest reductions in basal shear stress inland [Schmeltz et al., 2002] or the reduction in lateral and basal stress resulting from thinning and grounding line retreat [Schmeltz et al., 2002; Payne et al., 2004]. For PIG, at least, models of this scenario appear to explain the satellite observations effectively, but ice discharge from the TG increased only moderately over the same period through widening of its fast flowing section [Rignot et al., 2002], and so the nature of the grounded AS mass instability remains uncertain. Nonetheless, the synchronised thinning of three glacial systems has focussed attention on external disturbances downstream of the grounded ice. Here, we show that ice shelves of the AS sector have thinned due to unsteady ocean melting, reducing traction at the terminus of outlet glaciers ahead of a widespread drawdown of inland ice.

[4] We used European Remote Sensing (ERS-1 and ERS-2) satellite radar altimeter measurements to determine the 1992-2001 change in surface elevation of AS ice shelves relative to the WGS 84 Earth ellipsoid [Wingham et al., 1998]. From these data, we formed time-series of ice shelf elevation at crossing points of the ERS satellite ground track during 35-day orbit repeat cycles, the finest resolution afforded by the altimeters [Shepherd et al., 2001]. The altimeter ground footprint was $\sim 10 \mathrm{~km}$ in diameter, and the median separation of adjacent crossing point locations was $19 \mathrm{~km}$. This sampling procedure allowed us to accurately locate data points at the small floating ice shelves, which ranged from 50 to $120 \mathrm{~km}$ in stream-wise extent (Figure 1). We used ERS satellite radar interferometry [Rignot, 1996] to establish the landward limits of ice shelf tidal flexure and digital coastline data [Scientific Committee on Antarctic Research (SCAR), 1993] to bound their seaward barriers. In this way, we were able to exclude regions of grounded ice, sea ice and open ocean from our altimeter dataset. After adjusting for the periodic signal of ocean tides [Shepherd and Peacock, 2003; Shepherd et al., 2003], we combined the elevation time-series to determine the average 9-year rate of elevation change of the Abbot, Cosgrove, PIG, TG, Crosson, Dotson, and Getz ice shelves (Table 1).

[5] Between 1992 and 2001, the surface elevation of AS ice shelves lowered by up to $59 \pm 6 \mathrm{~cm} \mathrm{yr}^{-1}$ and all ice shelves showed falling elevation trends. A coherent pattern of ice shelf lowering was apparent, with the peak rate occurring at the TG ice shelf towards the centre of the Pine Island Bay, and progressively smaller rates to the east and west of this location. Although the lowering of the Abbot and Getz ice shelves at the margins of our study area were comparable to the variability of their elevation trends, the rates at other ice shelves were up to 15 times greater.

[6] To identify the nature of this lowering, we considered each factor affecting the surface elevation of AS ice shelves. The time rate of elevation change of an ice shelf surface relative to the ellipsoid is dependent upon a wide range of environmental conditions. For ice floating in hydrostatic 


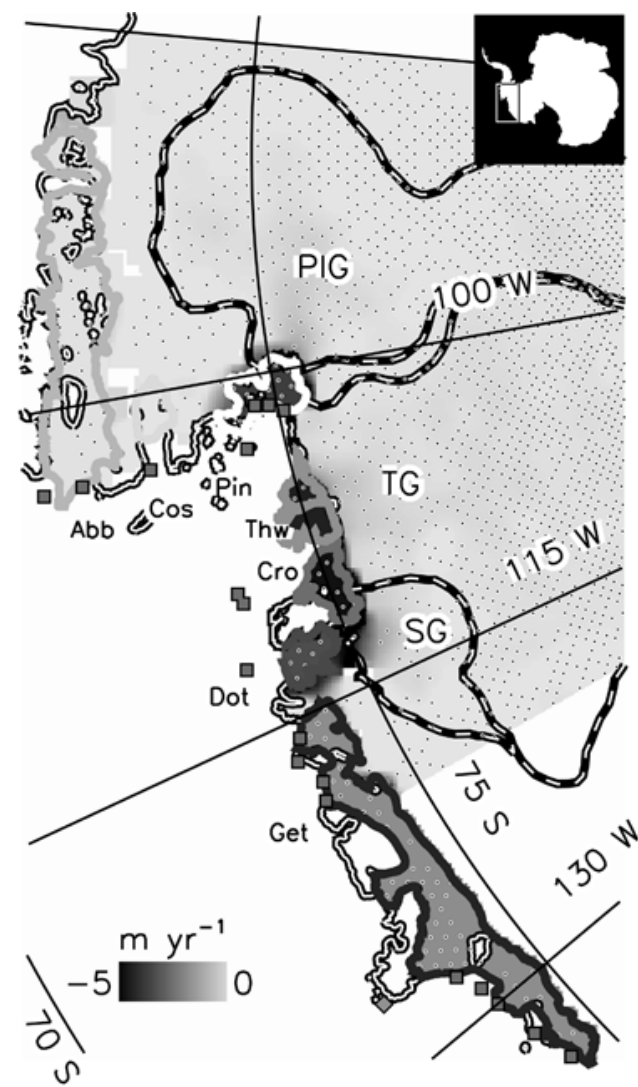

Figure 1. Average 1992-2001 rate of thickness change of floating ice shelves and grounded ice within the Amundsen Sea sector in West Antarctica (colour scale) superimposed on a mosaic of Advanced Very High Resolution Radiometer satellite imagery (grey scale). Boundaries of the Abbot, Cosgrove, Pine Island Glacier (PIG), Thwaites Glacier (TG), Crosson, Dotson, and Getz floating ice shelves are shown with coloured borders (cyan, blue, magenta, green, yellow, orange, and red, respectively). Also shown are the boundaries of the PIG, TG, and Smith Glacier (SG) ice drainage basins (black and white lines), locations of satellite radar altimeter data points used to determine thickness changes (black dots), ship stations where ocean temperature profiles were recorded (yellow squares), and the Mount Siple automatic weather station (green diamond). The greatest ice shelf thinning occurs at the terminus of the PIG, TG, and SG, major West Antarctic outlet glaciers. See color version of this figure in the HTML.

equilibrium and flowing with no vertical shear, elevation changes can be determined as the sum of contributions due to temporal changes in sea level height, ocean density, ice shelf density, surface and basal mass accumulation, and fluctuations in ice mass flux divergence [Shepherd, 2003]. Elevation changes due to fluctuations in mass are modulated by a factor (11 to $66 \%$ ) related to the density (ice to snow) at which they occur, according to the hydrostatic balance of the ice shelf and ocean; changes due to external factors or ice shelf density fluctuations are not. We estimated the uncertainty in ice shelf elevation due to external factors from records of eustatic sea level rise [Warwick et al., 1996], atmospheric pressure [Potter et al., 1985], ocean temperature [Jacobs et al., 2002], salinity [Whitehouse et al., 1996], and tides [Shepherd and Peacock, 2003], and that due to fluctuations in ice shelf density from a model of summer melting [Reeh, 1991] at the Mount Siple weather station (Figure 1) and density measurements at the PIG [Kellogg et al., 1985]. Their combined uncertainty was $40 \mathrm{~mm} \mathrm{yr}^{-1}$, an order of magnitude smaller than the peak rate we have recorded, and so the AS ice shelf lowering constitutes a widespread reduction in mass.

[7] Similarly, the expected fluctuation in elevation due to snowfall variability was only $46 \mathrm{~mm} \mathrm{yr}^{-1}$ [Wingham et al., 1998 ] and so the lowering must reflect the surface expression of a near-tenfold reduction in ice mass through reduced glacier influx or enhanced basal melting. The peak rate of thinning was $5.5 \pm 0.7 \mathrm{~m} \mathrm{yr}^{-1}$ at the TG ice shelf (Figure 1 and Table 1), and the geographical distribution was in close agreement with that recorded near to the grounding lines of the tributary glaciers [Shepherd et al., 2002]. Overall, the AS ice shelves lost 1 to $7 \%$ of their thickness during the 9-year period and, excluding the Abbot and Getz ice shelves where thinning rates were comparable to the measurement uncertainty, their combined ice mass loss was $45 \pm 5 \mathrm{Gt} \mathrm{yr}^{-1}$.

[8] For this negative imbalance to have arisen through reduced mass influx, a deficit must have occurred over the ice shelf advection timescales: 20, 40, and 80 years for the floating sections of the fast flowing PIG, TG, and SG, considerably longer for those elsewhere. However, since 1992 grounded ice upstream has thinned at a uniform rate due to an accelerating discharge [Joughin et al., 2003] that has exceeded the long-term accumulation mean [Shepherd et al., 2002], and the immediate response of floating ice downstream of such a perturbation would be to thicken. Whilst it remains a possibility that the ice shelf thinning is the result of some past episode of unbalanced ice flow that is now diminishing, there is no reason to suppose that flow disturbances originating inland would affect distinct glacial systems simultaneously. We conclude, therefore, that oceandriven melt rates beneath the AS ice shelves substantially exceed their equilibrium values. The average steady-state melt rate beneath the area of PIG included in our altimeter dataset is $11 \pm 1 \mathrm{~m} \mathrm{yr}^{-1}$ (from the data of Joughin et al. [2003] and the method of Joughin and Padman [2003]), and this, combined with our measurement of ice thinning, puts net melting at $15 \pm 2 \mathrm{~m} \mathrm{yr}^{-1}$.

[9] This conclusion is consistent with oceanographic data. We plotted our estimate of net melt rates beneath the AS ice shelves against ocean temperatures measured near to their base [Giulivi and Jacobs, 1997] (Figure 2), and the

Table 1. Area, Thickness, and Average 1992-2001 Rates of Elevation and Thickness Change of Ice Shelves Floating in the Amundsen Sea

\begin{tabular}{|c|c|c|c|c|}
\hline Ice Shelf & $\begin{array}{c}\text { Area } \\
\left(\mathrm{km}^{2}\right)\end{array}$ & $\begin{array}{l}\text { Ice thickness }{ }^{\mathrm{a}} \\
(\mathrm{m})\end{array}$ & $\begin{array}{c}\text { Elevation rate } \\
\left(\mathrm{cm} \text { year }^{-1}\right)\end{array}$ & $\begin{array}{c}\text { Thinning rate } \\
\left(\mathrm{m} \text { year }^{-1}\right)\end{array}$ \\
\hline Abbot & 30,827 & 419 & $-6 \pm 4$ & $0.6 \pm 0.4$ \\
\hline Cosgrove & 2,553 & 729 & $-8 \pm 3$ & $0.7 \pm 0.4$ \\
\hline Pine Island & 2,365 & 657 & $-42 \pm 4$ & $3.9 \pm 0.5$ \\
\hline Thwaites & 1,687 & 698 & $-59 \pm 7$ & $5.5 \pm 0.7$ \\
\hline Crosson & 3,843 & 776 & $-49 \pm 4$ & $4.5 \pm 0.5$ \\
\hline Dotson & 3,433 & 469 & $-36 \pm 2$ & $3.3 \pm 0.4$ \\
\hline Getz & 31,186 & 899 & $-17 \pm 6$ & $1.6 \pm 0.6$ \\
\hline
\end{tabular}

${ }^{\mathrm{a}}$ Derived from the empirical relationship of [Vaughan et al., 1995]. 


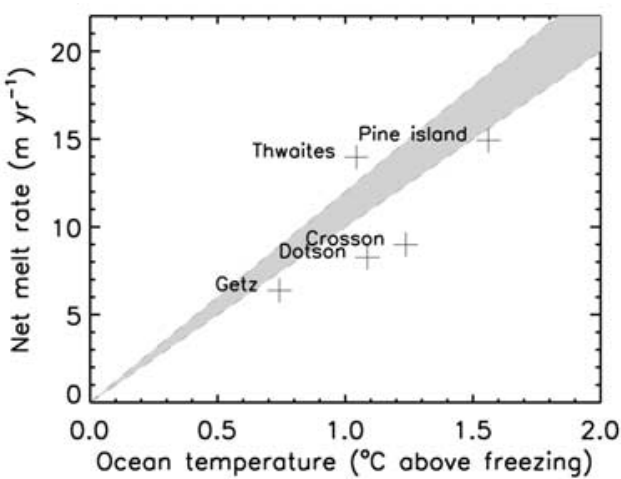

Figure 2. Estimated net melt rate $\left(B_{N e t}\right)$ at the base of ice shelves in the Amundsen Sea (AS) against ocean temperature above in situ freezing. $B_{N e t}$ includes both steady state melting $\left(B_{\text {Steady }}\right)$ - a major component of a balanced hydrological cycle - and ice shelf thinning rates derived from the altimeter data. $B_{\text {Steady }}$ was derived from considerations of mass conservation; at the Pine Island Glacier ice shelf (PIG), the average was $11 \mathrm{~m} \mathrm{yr}^{-1}$ (similar to that determined by Jacobs et al. [1996]), at other ice shelves we estimated the average from peak-rates determined close to their grounding lines [Rignot and Jacobs, 2002] and the spatial distribution of melting beneath the PIG [Joughin et al., 2003] - a reasonable assumption given the similarity between AS ice shelf stream-wise geometries. Ocean temperature was estimated beneath each ice shelf from vertical profiles recorded at 22 stations (see Figure 1) occupied during a 1994 cruise around Pine Island Bay [Giulivi and Jacobs, 1997]. The shaded area bounds empirical relationships for ice melting determined for a selection of Antarctic glaciers (lower curve [Rignot and Jacobs, 2002]) and laboratory samples (upper curve; from the data by Russel-Head [1980]). $B_{N e t}$ is positively correlated with ocean temperature $\left(\mathrm{r}^{2}=0.7\right)$, and the unsteady melting of AS ice shelves explains the twofold greater departure of $B_{\text {Steady }}$.

distribution of these data is comparable to empirical relationships derived from other measurements [Russel-Head, 1980; Rignot and Jacobs, 2002]. These relationships suggest that melt rates in the range 4 to $17 \mathrm{~m} \mathrm{yr}^{-1}$ are possible beneath AS ice shelves, with the greatest loss under the PIG shelf - in close agreement with our estimate. The temperature of water circulating in Pine Island Bay, which is fuelled by relatively warm circumpolar deep water [Jacobs et al., 1996], is therefore able to account for the ice shelf thinning. In addition to these considerations, repeat measurements of ocean salinity $1500 \mathrm{~km}$ east (downstream) of Pine Island Bay show that the Ross Sea has freshened at a rate of $\sim 46 \mathrm{Gt} \mathrm{yr}^{-1}$ during the past 40 years [Jacobs et al., 2002]. The combined release of mass from the grounded and floating ice of the AS sector is more than sufficient to explain this freshening.

[10] Since 1992, ice shelves of the AS sector of West Antarctica have thinned at rates that are 33 to $100 \%$ greater than their equilibrium ice influx. Overall, $92 \pm 12 \mathrm{Gt}$ of grounded and floating ice was lost each year during a 9 year period. We attribute this mass loss to unbalanced ocean melting. This provides a disturbance common to the PIG, $\mathrm{TG}$, and SG systems. Thinning reduces lateral traction, and, through grounding line retreat, basal traction. Computer simulations [Schmeltz et al., 2002; Payne et al., 2004] predict that these events lead to accelerated ice flow and thinning directly upstream, which can then diffuse rapidly further inland [Joughin et al., 2003; Payne et al., submitted manuscript, 2004]. To the extent these models reproduce the actual dynamics of AS outlet glaciers, enhanced ocean melting explains their synchronised imbalance [Shepherd et al., 2002]. Ocean currents on average $0.5^{\circ} \mathrm{C}$ warmer than freezing appear to have precipitated a sizable drawdown of ice from the WAIS interior. Elsewhere, ice shelf erosion [Shepherd et al., 2003] and disintegration have preceded increased discharge from glaciers upstream [De Angelis and Skvarca, 2003]. The consequences of a warming ocean on the grounded Antarctic ice mass needs more attention than it has received to date [Warwick et al., 1996].

[11] Acknowledgments. Supported by the United Kingdom Natural Environment Research Council Centre for Polar Observation and Modelling. We thank the European Space Agency for provision of ERS data, S. Jacobs for access to ocean temperature data, I. Joughin for PIG velocity data, and A. J. Payne for valuable comments on the manuscript.

\section{References}

De Angelis, H., and P. Skvarca (2003), Glacier surge after ice shelf collapse, Science, 299, 1560-1562.

Giulivi, C. F., and S. S. Jacobs (1997), Oceanographic data in the Amundsen and Bellingshausen Seas: N. B. Palmer cruise 9402, February-March 1994, Tech Rep LDEO-97-3, 330 pp., Lamont-Doherty Earth Obs., Pallisades, New York.

Jacobs, S. S., H. H. Hellmer, and A. Jenkins (1996), Antarctic ice sheet melting in the Southeast Pacific, Geophys. Res. Lett., 23, 957-960.

Jacobs, S. S., C. F. Giulivi, and P. A. Mele (2002), Freshening of the Ross Sea during the late 20th century, Science, 297, 386-389.

Joughin, I., and L. Padman (2003), Melting and freezing beneath FilchnerRonne Ice Shelf, Antarctica, Geophys. Res. Lett., 30(9), 1477, doi:10.1029/2003GL016941.

Joughin, I., E. Rignot, C. E. Rosanova, B. K. Lucchitta, and J. Bohlander (2003), Timing of Recent Accelerations of Pine Island Glacier, Antarctica, Geophys. Res. Lett., 30(13), 1706, doi:10.1029/2003GL017609.

Kellogg, T. B., D. E. Kellogg, and T. J. Hughes (1985), Amundsen sea sediment coring, Antarct. J. U.S., 20, 79-81.

Mercer, J. H. (1978), West Antarctic Ice sheet and $\mathrm{CO}_{2}$ greenhouse effect: A threat of disaster, Nature, 271, 321-325.

Payne, A. J., A. Vieli, A. P. Shepherd, D. J. Wingham, and E. Rignot (2004), Recent dramatic thinning of largest West Antarctic ice stream triggered by oceans, Geophys. Res. Lett., 31, L23401, doi:10.1029/ 2004GL021284.

Potter, J. R., J. G. Paren, and M. Pedley (1985), Tidal behaviour under an Antarctic ice shelf, Br. Antarct. Surv. Bull., 68, 1-18.

Reeh, N. (1991), Parameterization of melt rate and surface temperature on the Greenland Ice Sheet, Polarforschung, 59, 113-128.

Rignot, E. (1996), Tidal motion, ice velocity and melt rate of Petermann Gletscher, Greenland, measured from radar interferometry, J. Glaciol., 42, 476-485.

Rignot, E. (1998), Fast recession of a West Antarctic glacier, Science, 281, $549-551$.

Rignot, E., and S. S. Jacobs (2002), Rapid bottom melting widespread near Antarctic ice sheet grounding lines, Science, 296, 2020-2023.

Rignot, E., D. G. Vaughan, M. Schmeltz, T. Dupont, and D. MacAyeal (2002), Acceleration of Pine Island and Thwaites Glaciers, West Antarctica, Ann. Glaciol., 34, 189-194.

Russel-Head, D. S. (1980), The melting of free-drifting icebergs, Ann. Glaciol., 1, 119-122.

Schmeltz, M., E. Rignot, T. K. Dupont, and D. R. MacAyeal (2002), Sensitivity of Pine Island Glacier, West Antarctica, to changes in ice-shelf and basal conditions: A model study, J. Glaciol., 48, 552-558.

Scientific Committee on Antarctic Research (SCAR) (1993), Antarctic Digital Database [CD-ROM], Cambridge, UK.

Shepherd, A. (2003), Larsen ice shelf has progressively thinned, Science, 302, 856-859. (Correction (2004), Science, 303, 1612.)

Shepherd, A., and N. R. Peacock (2003), Ice shelf tidal motion derived from ERS altimetry, J. Geophys. Res., 108(C6), 3198, doi:10.1029/ 2001JC001152. 
Shepherd, A., D. J. Wingham, J. A. D. Mansley, and H. F. J. Corr (2001), Inland thinning of Pine Island Glacier, West Antarctica, Science, 291, $862-864$.

Shepherd, A., D. J. Wingham, and J. A. D. Mansley (2002), Inland thinning of the Amundsen Sea sector, West Antarctica, Geophys. Res. Lett. 29(10), 1364, doi:10.1029/2001GL014183.

Shepherd, A., D. Wingham, T. Payne, and P. Skvarca (2003), Larsen ice shelf has progressively thinned, Science, 302, 856-859.

Thomas, R. H., and E. Rignot (2004), Force-balance analysis of Pine Island Glacier suggests cause for recent acceleration, Ann. Glaciol., in press.

Vaughan, D. G., J. Sievers, C. S. M. Doake, H. Hinze, D. R. Mantripp, V. S. Pozdeev, H. Sandhager, H. W. Schenke, A. Solheim, and F. Thyssen (1995), Subglacial and seabed topography, ice thickness and water column thickness in the vicinity of Filchner-Ronne-Schelfeis, Antarct. Polarforsch, 64, 75-88.

Warwick, R., C. Le Provost, M. Meier, J. Oerlemans, and P. L. Woodworth (1996), Changes in sea level, in Climate Change 1995: The Science of Climate Change, edited by J. T. Houghton et al., pp. 359-405, Cambridge Univ. Press, New York.

Whitehouse, M. J., J. Priddle, and C. Symon (1996), Seasonal and annual change in seawater temperature, salinity, nutrient and chlorophyll a distributions around south Georgia, South Atlantic, Deep Sea Res. Part I, 43, 425-443.

Wingham, D. J., A. Ridout, R. Scharroo, R. Arthern, and C. K. Shum (1998), Antarctic elevation change from 1992 to 1996, Science, 282, $456-458$.

E. Rignot, Jet Propulsion Laboratory, California Institute of Technology, Mail Stop 300-235, Pasadena, CA 91109-8099, USA

A. Shepherd, Centre for Polar Observation and Modelling, Scott Polar Research Institute, University of Cambridge, Cambridge CB2 1ER, UK. (aps46@cam.ac.uk)

D. Wingham, Centre for Polar Observation and Modelling, University College London, London WC1E 6BT, UK. 